Sweden, Australia and New Zealand; but Bob lived and worked in Edinburgh for over a quarter of a century.

Along the way, Bob picked up the Gaskell Gold Medal in our own College and served as examiner to many other Colleges. He sat on the board of at least six professional journals and produced a string of seminal books, chapters and articles on every key issue in psychiatry, from the philosophy of service to the intricate epidemiology of illness. He was adviser to a host of national and world organisations and was showered with honorary fellowships at home and abroad. He was a Foundation Fellow of both our own College and of the Academy of Medical Sciences and was made an Honorary Fellow in 2000. Appropriately enough, he was made a Commander of the British Empire for services to education in 1992. Bob was Chief Medical Officer for Scotland (1991-1996) and President of the Royal College of Psychiatrists (1996-1999) through some of the most turbulent times in politics and the profession, respectively.

So much for statistics. What they reflect is a life-long commitment to four key areas - research, teaching, politics and the practice of psychiatry. There are academic departments across the world who were inspired by the rigour of his inquiry; there are exam students who have blessed the name of Kendell et al; there are audiences whose minds have fizzed for weeks with ideas injected like depots; and there are politicians who have learnt much (sometimes only too painfully) from his insight. Above all, the College, its staff, Officers and members grew to admire and depend upon the strength that he gave us as our first fulltime President at 17 Belgrave Square.

What Bob brought to all these areas was a fascination with his subject, a passionate pursuit of knowledge, a puritan attention to getting the details right, an unwavering moral honesty and the courage to speak his mind, whatever the circumstances. It was a set of qualities sometimes difficult for the rest of us to live up to. Bob did not suffer fools gladly in College committee, Government or taxi-rank. But if you stuck with it, you were rewarded with a wry smile, a hand on the shoulder, a quiet pint over discussion of the arts or a trip to the Andes and, best of all, a delicious snippet of gossip about a former colleague; in short, with friendship.

Bob was an incredibly fit man, in every sense. He would dash off in mid-sentence to run after a bus, jump on its platform and expect you to be there to continue the conversation. He swam his customary 40 lengths the day before he died and was hard at work at his computer the morning he did so. At post-mortem examination, he was revealed to have a brain tumour and his death, at least, spared him a slow physical and cognitive decline that would have been hard for a man like Bob to

bear. But it is difficult to believe that he has gone.

Bob leaves a wife, Ann, a consultant anaesthetist and as much a part of the College as he was, four children, Katherine, Judith, Patrick and Harry, one grandchild, Ewan, and "two pending". He leaves the rest of us the memory of a man at the peak of his powers. Despite what you said in that letter, Bob, you knew a lot about everything. I shall miss your wise counsel. My wife, Mary, misses your wicked sense of fun. And she isn't often wrong about things like that!

Mike Shooter

\section{Edgar Leon Udwin}

\section{Formerly Director of}

Broadmoor Hospital, Crowthorne, Berkshire

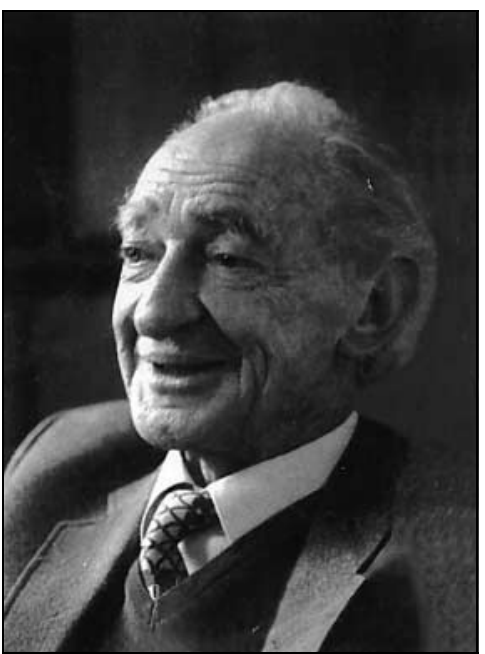

Edgar was born in Johannesburg, South Africa, on 28 March, 1918, and died aged 84 in London on 17 October, 2002, after a long and distressing cardiac illness.

He was educated at King Edward's School in Johannesburg and studied medicine at Witwatersrand University, where he qualified MB, ChB in 1942. After the conventional jobs in South Africa, he grabbed the first opportunity after the War to widen his horizons and to gain graduate experience in London. This he fulfilled with a six-month stint at Hammersmith Graduate Hospital.

In 1948, he was joined in London by his fiancée, Alison Jacques, a physiotherapist by profession, and they were married at Hampstead Registry Office in 1949. After not very long, Edgar and Alison succumbed to the magnetism of London, and were persuaded to forego the sunny climes of Africa for the cold and culture of England and beyond.

Again, in 1949, Edgar decided that psychiatry was his true vocation and to that end he joined me as a registrar at Horton Hospital, Epsom, thus beginning an association as a colleague and firm friend to survive for over half a century.

Quite fortuitously, a cottage, formerly occupied by a gate-keeper on the Horton estate, became vacant and his post abolished. The newly-weds jumped at the opportunity to take it over and, with the assistance of Edgar's DIY expertise plus Alison's impeccable taste the humble cottage was converted into a warm, welcoming abode. West Cottage as it was styled, not only served to bring up the Udwin's three children, but became an important focal point for social events at Horton.

For the duration of World War II, Horton had done duty at a War Hospital and at the time Edgar joined us, the evacuation of the military was just about completed. The opportunity arose, therefore, to convert the shell of a war hospital into a modern psychiatric hospital. This was a formidable challenge and that we succeeded was in no small measure, due to Edgar's initiative and hard work.

Edgar stayed at Horton for 13 years time for him to move on. A vacancy for a consultant arose at Broadmoor Specialist Hospital which, with his interest in forensic psychiatry, seemed eminently suitable. I encouraged him to apply. He did, and I was not in the least surprised when he was selected.

A major attraction of working at Broadmoor was that it was under the leadership of Dr Patrick McGrath, CB, CBE, one of England's most distinguished forensic psychiatrists. Broadmoor, at that time, was undergoing the transition from an old-time penal institution to a vibrant, modern psychiatric hospital. As he had been at Horton, Edgar was in step with the transition and, as he had at Horton, made a valuable contribution.

So valuable, indeed, was his contribution that when Dr McGrath retired, Edgar was persuaded to become director, a post he held with distinction until his retirement in 1983.

If I were to be asked to pin-point Edgar's finest achievement, I would state categorically that he had been instrumental in the discharge of an army of long-stay patients into the community, or to conventional mental hospitals, who could no longer pose a danger to the public.

Edgar left behind a devoted family, his wife Alison and his three children, Mark, Candy and Emma.

Henry R. Rollin

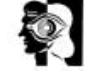

columns 